\title{
bioengineering
}

ISSN 2306-5354

www.mdpi.com/journal/bioengineering

Review

\section{Trends in Upstream and Downstream Process Development for Antibody Manufacturing}

\section{Petra Gronemeyer, Reinhard Ditz and Jochen Strube *}

Institute for Separation and Process Technology, Clausthal University of Technology, Leibnizstraße 15, D-38678 Clausthal-Zellerfeld, Germany; E-Mails: gronemeyer@itv.tu-clausthal.de (P.G.); ditz@itv.tu-clausthal.de (R.D.)

* Author to whom correspondence should be addressed; E-Mail: strube@itv.tu-clausthal.de; Tel.: +49-5323-722200; Fax: +49-5323-723570.

External Editor: Christoph Herwig

Received: 1 August 2014; in revised form: 12 September 2014 / Accepted: 29 September 2014 / Published: 1 October 2014

\begin{abstract}
A steady increase of product titers and the corresponding change in impurity composition represent a challenge for development and optimization of antibody production processes. Additionally, increasing demands on product quality result in higher complexity of processes and analytics, thereby increasing the costs for product work-up. Concentration and composition of impurities are critical for efficient process development. These impurities can show significant variations, which primarily depend on culture conditions. They have a major impact on the work-up strategy and costs. The resulting "bottleneck" in downstream processing requires new optimization, technology and development approaches. These include the optimization and adaptation of existing unit operations respective to the new separation task, the assessment of alternative separation technologies and the search for new methods in process development. This review presents an overview of existing methods for process optimization and integration and indicates new approaches for future developments.
\end{abstract}

keywords: process development; upstream processing; downstream processing; process integration; host cell proteins 


\section{Introduction}

Due to their broad application range, monoclonal antibodies $(\mathrm{mAb})$ are used worldwide in a variety of applications such as therapeutics or in diagnostics [1-3]. Increasing product demands in combination with a market introduction of biosimilars call for less and less expensive products in order to remain competitive [4]. The current rather expensive production processes need to be improved significantly. Innovation in technological development as well as production processes are to be pursued $[1,4]$. However, it is not only necessary to improve process development and implement new unit operations. The products themselves also need attention [4,5]. Improvements in antibody quality and the development of more efficient and more economic processes are required [4,5].

Significant progress has been achieved by optimization of upstream processing (USP) in the last two decades. Process efficiency, achievable cell densities and product titers could be increased enormously in cell culture processes $[1,2,5-8]$ by developing recombinant technologies as well as media and process control strategies $[1,2,6,7]$. Today, antibody concentrations of $3-5 \mathrm{~g} / \mathrm{L}$ are achieved routinely and some companies have attained up to $10-13 \mathrm{~g} / \mathrm{L}$ in fed-batch processes $[5,6,8]$. Antibody titers of up to $25 \mathrm{~g} / \mathrm{L}$ via modified perfusion have been reported as well [7,9].

Upstream titers depend mostly on biological limits (e.g., cell line or media optimization) and can be raised without an increase in costs. USP manufacturing processes which generate higher titers still take place in the same reactor set-ups like earlier processes of lower titers. Consequently, the processed volumes are the same but the amount of antibody is increased. This results in feed volumes which contain 15-100 kg mAb/batch at titers of $5 \mathrm{~g} / \mathrm{L}$ in $20-25 \mathrm{~kL}$ bioreactors instead of 5-10 kg mAb/batch [6,8]. These feed volumes enter the facilities of downstream processing (DSP) which were designed for much lower amounts of antibody. The equipment reaches its physical limits and therefore, its capacity limits, resulting in an increase of processing time, material consumption and costs.

Consequently, upstream capacity can be increased without raising the costs whereas downstream capacity always scales at least linearly with costs due to its physical principles for separation. At low product titers, upstream manufacturing is more expensive than DSP but higher titers shift the main manufacturing costs from USP towards DSP [7,8,10,11] and lead to a non-linear increase of overall costs for the manufacturing process [10]. This problem is amplified by a change in type and concentration of impurities which emerge from process changes during product titer optimization [12-16]. These modifications of broth compositions are an additional challenge for the downstream processing.

In search of a solution for this "downstream bottleneck", new approaches of optimization strategies and technology development are necessary. Innovative technologies should increase the maximum capacity and allow the handling of high titer volumes.

\section{State of the Art in Process Development and Optimization}

The current manufacturing technology for antibodies can be divided in development and optimization of USP and DSP. The development of technological platforms was possible in process development and consequently in manufacturing [16]. Examples can be cell line selection, media optimization or harvesting methods on the USP side [2,17] or the optimization of individual unit operations on the DSP side $[16,18,19]$. The optimization of process and product analysis is also platform-based. This 
standardization of development steps takes place inside the company and aims at a decrease of investment, time and development cost per antibody [2,8,16-19]. In addition, material purchase and storage, scale up, process transfer are simplified $[2,8]$ and the number of potential unit operations is reduced [2,19]. One example for the development of a manufacturing platform is published by Vogel et al. (2012) [20]. It is applied on a blood coagulation factor and the authors include an outlook on necessary process changes for antibody manufacturing.

Due to the intense time pressure in process development, high-throughput (HTP) methods are employed in early process development [21,22]. They permit running a large number of screening experiments in a very small scale and can be performed with minimal amounts of material. Large amounts of data are provided in a short period of time [21-25]. HTP methods are often combined with statistically planned experiments (Design of Experiments, DoE). In statistically planned experimental designs, several factors can be changed within one set of experiments. These experimental designs take into account the number and type of factors, already existing information and reliability of the results. Classical designs are full factorial, fractional factorial or response surface designs. By applying DoE, a small number of experiments is sufficient to determine the influence of several parameters and to identify the most significant ones. HTP methods and DoE are both applied in the development of upstream as well as downstream processing [21,26-32].

Furthermore, concepts of Quality by Design (QbD) in combination with HTP methods or DoE [33,34] are encouraged to be applied in process [35-38] and analytical development [33,34]. QbD is a manufacturing principle in which product quality is built into the manufacturing process by understanding the associated risks and including strategies to mitigate those risks during manufacture [35-38]. The implementation of QbD shall lead to the development of more robust and efficient manufacturing processes of mAbs with increased clinical efficacy [36]. Horvath et al. (2010) [39] described a QbD-based optimization approach in cell culture technology. Harms et al. (2008) [40] as well as Abu-Absi et al. [41] published case studies on mapping design space for fermentation and cell culture. In DSP, Jiang et al. (2010) [35] described a case study on the application of QbD principles for hydrophobic interaction chromatography and Pathak et al. (2014) [34] as well as Michels et al. (2012) [33] published examples for QbD-based development of analytical methods for antibody aggregates and size heterogeneity.

\subsection{Process Development in Upstream Processing}

Process development and optimization in USP includes various parts: cell line development and engineering, cell clone selection, media and feed development, bioprocess development and scale up [5,9,42-44]. Reactor design, cell harvesting, process control and the corresponding analytics can be part of the optimization process as well $[9,42,43]$. These areas are optimized individually and focus on a robust generation of a high product titer, high productivity and defined quality [5,6,43]. Figure 1 schematically presents the different optimization areas and lists the most important parameters. Following process development, process characterization, process transfer and set up of a cGMP-production take place in combination with process validation [5]. 
Figure 1. Optimization areas and parameters in upstream processing.

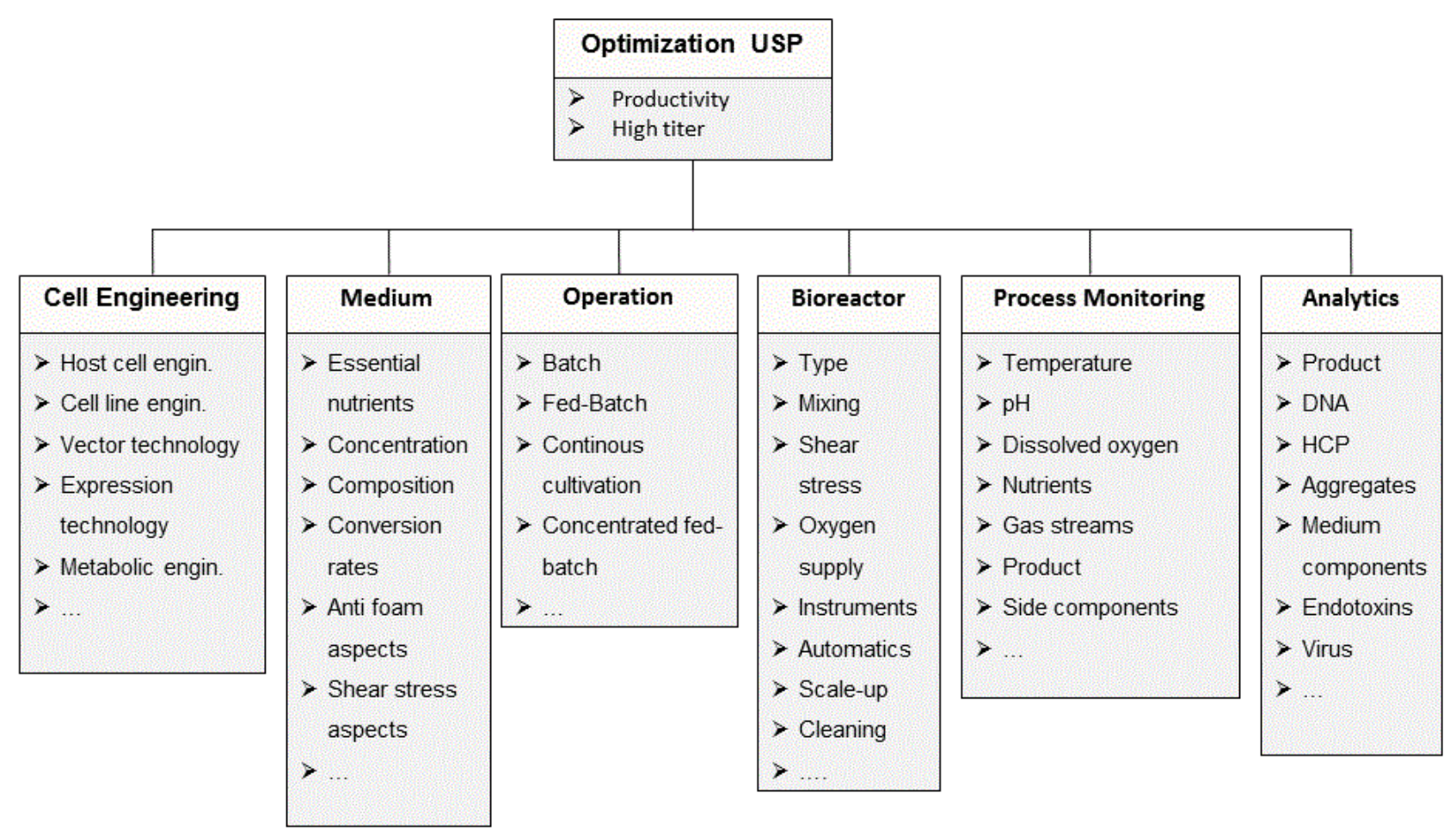

\subsubsection{Cell Line Development and Clone Selection}

In the course of cell line development, a company-internal selection of host cells, expression vectors, transfection and selection methods takes place. The selection of the expression system is determined by its ability to ensure a high productivity and defined quality criteria $[5,25,43]$. The expression system most commonly used for the production of monoclonal antibodies or recombinant proteins are Chinese Hamster Ovary $(\mathrm{CHO})$ cells $[5,8,9,43,45]$. The first proteins produced by CHO-derived cell lines were recombinant interferons and tissue-type plasminogen activator (tPA) [25]. In 2010, approximately $70 \%$ of all recombinant proteins have been produced in CHO cells [5].

High productivity and posttranslational processing are the criteria for cell line selection after cell transfection. Other factors, such as growth behavior, stable production, cultivation in serum-free suspension media, adaptive behavior, amplification, clone selection and possible risk assessment are taken into account as well [5,43]. Li et al. (2010) [5] and Costa et al. (2010) [43] provide good overviews of current methods for optimizing expression vectors and transfection methods. Several methods for cell line optimization are employed prior to cell clone selection to improve and ensure product quality $[5,44,46]$. One important parameter of product quality is the reproducibility of the glycosylation profiles. These depend on the respective cell clone, medium and cultivation conditions $[5,9,44,47]$. Commonly used methods are RNAi and gene deletion technologies [48,49]. Other approaches in cell engineering help to avoid ammonium and lactate accumulation [50-52] and improve cell growth [53]. Codon optimization and various approaches for gene-amplification via different selection markers serve to optimize the cell line [44]. Further approaches include metabolic engineering or anti-apoptosis enhancements. Costa et al. (2010) provide additional resources on cell engineering and its aspects [43]. 
The subsequent selection of the best suited cell clone is one of the most important steps of the upstream development process as variations in the production cell line during clinical development constitute a major process change. Such a change requires an additional proof of product comparability. The cell clones considered for final production have to fulfill the required product quality, processability and volumetric productivity [43,54]. Criteria for selection are: growth, cell-specific and volumetric productivity, glycosylation profiles, development of charge variants, aggregate formation, protein sequence heterogeneity and clone stability among others [5,54,55]. In addition, metabolic characteristics can be exploited for cell clone selection, as well as their stability, robustness, high viability and low lactate or ammonium generation. At the end, process performance in the bioreactor decides which clone will be used for production and which will be saved as a backup. Running this selection process in the shortest time possible presents a big challenge. Especially product quality, productivity, and the metabolic profiles of the cells strongly depend on cell culture conditions [5].

Transient gene expression (TGE) as another possibility of protein production should be mentioned at least briefly. TGE is used to produce recombinant proteins over a short period of time following a DNA transfer into single-cell suspension cultures. There is no need for genetic selection of transfected cells and therefore a lot of time is saved [25,56-58]. Today, TGE is applied as a screening-tool for drug development since only small doses of potential drugs are needed within a short amount of time [56]. IgG yields of $2-80 \mathrm{mg} / \mathrm{L}$ have routinely been achieved with this process [56,57] which can be increased of $250-300 \mathrm{mg} / \mathrm{L}$ [58]. For industrial purposes, transient gene expression is promising regarding its high time-savings in cell line development. For manufacturing processes, it is likely to be tried with low-dose proteins before an application for antibody-derived products will be attempted [25,57].

In this review, concepts of process optimization on a cellular level are described mostly on an academic level due a restricted publishing of industrial owned knowledge on process optimization strategies. In industrial process development, the optimization of media and process conditions is primarily used to create more cells and therefore more product. This resulted in processes of up to 21 days' cultivation time, increased viabilities and cell densities 10-15 times higher than in the 1980s [25].

\subsubsection{Media Development and Optimization}

Media optimization processes have led to progress in commercially available media over the last decades. Early cell culture media like Ham's F10 or Dulbecco's Modified Eagle Media were based on blood serum supplements. These include a complex mixture of unknown components. In the 1970s and 1980s, many serum-free media were developed in order to provide better defined cultivation media like IMDM or CMRL medium. Further improvements eliminated all animal-derived components to avoid pathogen contaminations and thus resulting in chemically defined media $[17,27,59,60]$.

Media development is a key factor in improving productivity and growth behavior of cells but it also influences product quality [26]. Today, commercially available media present the basis for media development towards optimized conditions for a process using a specific cell line. The optimal blend of media components has to be solved individually due to the high diversity of cell lines, processes, media components, interactions of components and metabolic pathways. Effective media development depends strongly on the choice of optimization tools. The most common strategies are based on: component titration, media blending, spent media analysis and automated screening $[26,59,61]$. 
A combination of these methodologies provides the most rational way of media development. The development process itself includes a screening process to identify important components, followed by an optimization step and a verification of the process [59]. Standardization of these development approaches led to a platform-based media development [30].

Traditionally, media were developed by changing one factor at a time [26,27]. In order to reduce experimental efforts, DoE and high-throughput methods are applied in industrial development processes [30-32]. As an example, a top down approach is described by Ma et al. (2009) [62]. Media development needs to be optimized for each cell line individually but its establishment as a platform process in development leads only to an improvement of USP. There is still some potential for optimization which can be drawn upon, if necessary [5].

Approaches for feed media development include variations in the concentration of the basal medium, nutrient consumption $[27,61,62]$, accumulation of impurities and a balance of cell growth and volumetric productivity [63]. Generally, methods for feed media optimization are the same as in basal media optimization, including the use of DoE [29].

\subsubsection{Development of Process Strategies}

Continuous processes in USP are already well established for unstable products. Continuous by-product removal and nutrient addition extend the cultivation time. A short retention time of the product preserves the product quality. The major advantage consists in high cell number and high productivity in a small-sized bioreactor [64-68]. This process is more challenging regarding technique and sterility. It produces large harvest volumes and requires large media volumes than batch or fed-batch processes $[65,67,68]$. Perfusion processes are applied in biopharmaceutical production and can also be used for high density seed bioreactors and cell bank manufacturing [66,67]. Cell retention devices are of high importance for the removal of fermentation broth from the reactor [64,66-70]. They can be divided into filtration- and acceleration-based devices. In addition to effective cell retention, they have to be robust [64,67] and scalable [69]. Gravity-based cell settlers, spin filters, centrifuges, alternating tangential-flow filters, vortex-flow filters, acoustic settlers and hydrocyclones are commonly used in small scale applications [64,69] but only few of them can be adapted to a larger scale. Scalable devices are mostly based on filtration, gravity settling and centrifugation. Pollock et al. (2013) [68] provide an overview of industrially applied retention devices in continuous antibody manufacturing. Internal spin-filters are used in production volumes of up to $500 \mathrm{~L}$, and external ones up to $1000 \mathrm{~L}$. On a larger scale, mostly gravity settlers are used [68]. A comprehensive overview of principles of sedimentation, centrifugation and filtration as cell retention devices is provided by Henzler (2012) [71].

Recent developments resulted in a new device, called the ATF System (Refine Technology) [7,66-69]. The system uses tangential flow filtration with an alternating cell broth flow direction. A diaphragm pump is used to alternate these directions without additional shear stress and a cycle time of about 1 min. The back flush created by the alternated movement reduces possible fouling effects [66,67]. This system is easy to scale up and presents a possibility for single-use applications in USP [67,69]. It is used to generate ultra-high-density cell cultures such as concentrated fed-batch and concentrated perfusion processes [69]. Cell densities up to $2.14 \times 10^{8}$ cells $/ \mathrm{mL}$ [67] as well as product titer of up to $25 \mathrm{~g} / \mathrm{L}$ are reached [7]. 
The choice of a fed-batch or continuous process depends mostly on product quality issues, existing facilities and experiences. The development and optimization concentrates on defining optimal operation parameters including among others temperature shifts, gas exchange, shear stress, transfection process, feeding strategy, duration of the cultivation and perfusion rate [2,17,23,65,72-74]. This part of development aims for high cell numbers, defined product quality, high titer und an extension of fermentation duration $[17,73,74]$ and is mostly performed by use of DoE. The same criteria are valid for the choice of a bioreactor system.

\subsubsection{Optimization of Bioreactor Systems}

A new trend addresses an implementation of single-use bioreactor systems. They have the advantages of lower capital investment and operational costs, flexibility [75-77], improved production scheduling and higher process replication [75,76]. They are applicable for GMP manufacturing and available up to 2000 L in scale [76,77]. Different designs of single-use reactors are available, such as wave, orbital shaken, pneumatically mixed and stirred tank bioreactors [75,77-80]. They eliminate the need for cleaning or sterilization and, thus, significantly reduce contamination rates [76,80]. One new bioreactor system, based on cylindrical or square-shaped vessels which are orbital shaken, distinguishes itself by high gas transfer rates through surface aeration and a working scale of up to $2500 \mathrm{~L}$ as a disposable reactor [25]. First descriptions and simulations of fluid motions in these vessels were published by Reclari et al. (2014) [81]. Other disposable bioreactors have been developed based on a bag concept [80]. They are used not only in research but also in manufacturing processes in mini- and mid-scale as well as seed trains in perfusion mode. However, there is still a lot of work to be done in optimizing disposable bioreactor systems, especially in terms of aeration and mixing [78,80]. Up to now, the scale is limited up to $2000 \mathrm{~L}-2500 \mathrm{~L}$ [25,76,77], the diversity of options is restricted, and there is a lack in standardization, instrumentation and some remaining performance issues. Furthermore, there is a shortage of a validation process concerning the nature, quantity and risk of leachables and extractables from the disposable plastics $[76,79,80]$. The bags can also bind media components thus, decreasing the process performance [80]. These problems are currently in focus of development activities.

For similar production organisms and growth behavior, the development a generic harvest process [16], which consists mostly of a depth filtration or a centrifugation [2,16], could be attractive. Recently, depth filters have been shown to absorb soluble impurities, like proteins or DNA. An implementation of such a filter needs to be investigated in terms of a process integration [2]. Other developments include flocculation as a primary recovery step [16]. For products which are not completely compatible with the platform, additional development is necessary [16].

All development and optimization approaches in USP provide an increase in monoclonal antibody concentration from $50 \mathrm{mg} / \mathrm{L}$ in 1986 to $5-20 \mathrm{~g} / \mathrm{L}$ today $[7,8,82]$. In spite of these achievements, the focus of optimization often neglects the drawbacks of impurities. Impurities will only be considered if they are highly toxic or if changes in their metabolic routes result in a higher production of the desired product. Considerations regarding subsequent separation problems are carried out rarely $[1,13]$. 


\subsection{Process Development in Downstream Processing}

DSP development focusses on yield and productivity as well as on purity and process capacities. An increase in separation efficiency of single unit operations is achieved by expansion of existing facilities and by optimization of existing and alternative processes [2]. New methods for process development are under investigation. These include the establishment of platform technologies, high-through-put methods with approaches based on $\mathrm{QbD}$ and DoE-based experimental optimizations [2,21,36]. Additionally, an integration of modeling and simulation of unit operations as well as the use of mini-plant facilities is applied in process development (see Figure 2).

Figure 2. Optimization fields in downstream processing.

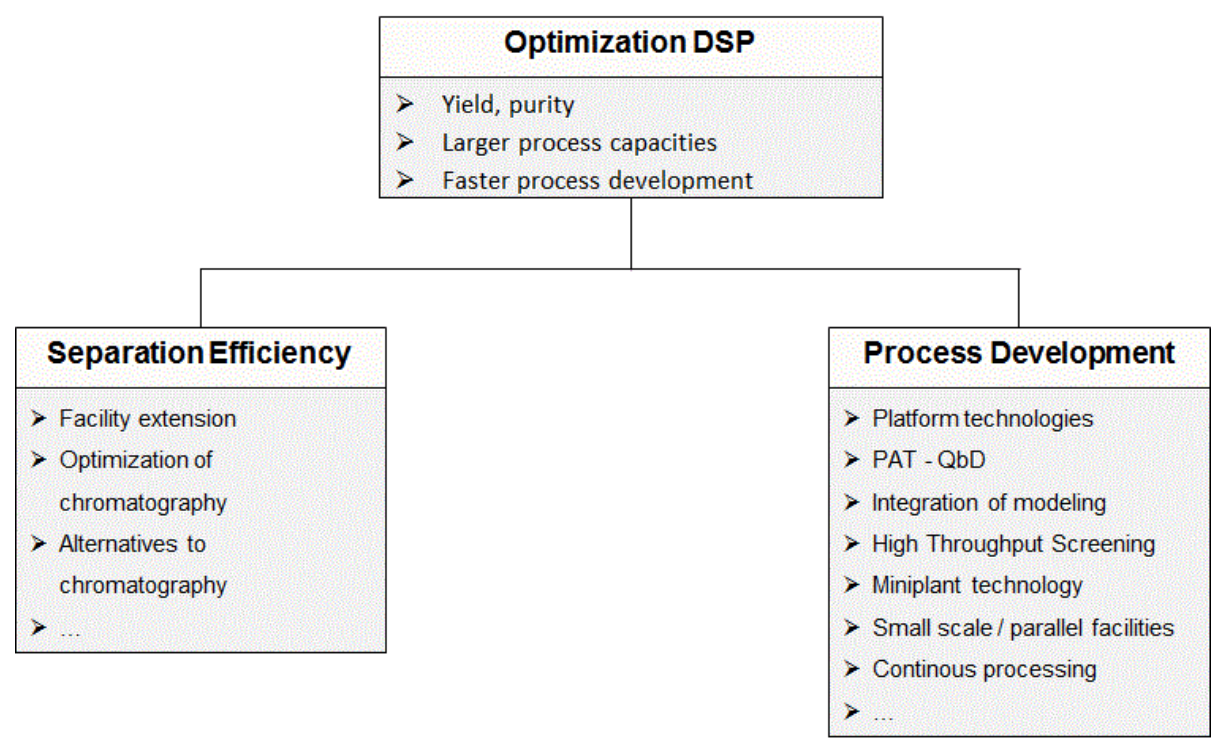

Figure 3. Schematic manufacturing process of monoclonal antibodies from cell culture [84].

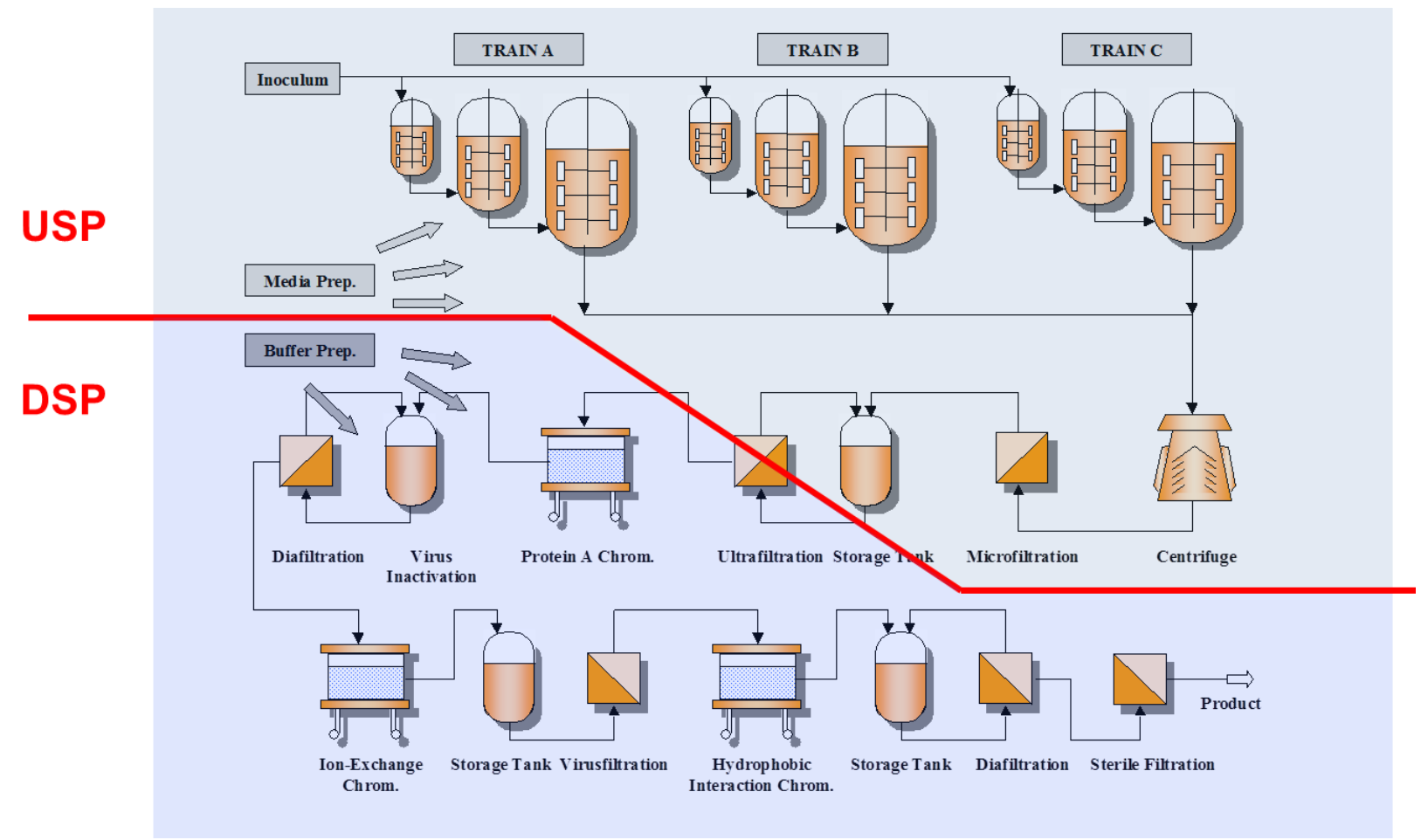


Traditionally, monoclonal antibodies were purified by a sequence of different chromatographic and membrane-based operations $[2,7,8,11,16,83,84]$. A virus-inactivating operation, a filtration-based virus-reducing step and a final diafiltration have to be included [1,7,16,17,83,84]. Figure 3 represents a typical process for antibody purification. A selected number of these individual steps are discussed in more detail in the following sections.

\subsubsection{Chromatographic Separations}

After cell harvesting by centrifugation or filtration, a chromatographic separation unit is used to isolate antibodies from fermentation broth $[2,8,16,18,84,85]$. Protein A chromatography is one of the most important unit operations for antibody capturing $[16,85,86]$. It distinguishes itself by high selectivity towards IgG-type antibodies, high flow rate and capacity. The dynamic binding capacity ranges from 15-100 g mAb/L resin depending on antibody, flow rate and adsorbent $[16,87,88]$. The degree of purity is consistently higher than 95\% [4,85,86,89]. Process-related impurities like HCP, DNA, media components and virus particles are removed $[16,85,86]$. One of the major advances in recent years of process development consists in a better integration of chromatography to the overall manufacturing process. Elution conditions of the initial Protein A capture step are adjusted to the following unit operation in order to enter a subsequent virus inactivation step or an ion exchange chromatography [16]. This eliminates any need for buffer exchange between these unit operations and it is one example for a successful integration of single separation operations during the last decades.

Problems exist in form of Protein A leaching and non-specific binding of impurities like HCP and DNA. Leached Protein A reduces the binding capacity of Protein A chromatography and needs to be removed in subsequent purification steps $[16,86,90]$. The amount of bound impurities depends on the adsorbent, composition of cell culture harvest, column loading and washing conditions [16,86]. Tarrant et al. (2012) [86] and Shukla et al. (2008) [85] published studies on HCP interacting with different Protein A matrices and the product.

Cation exchange chromatography (CEX) presents an alternative to Protein A chromatography [7,16,88,89]. It requires a $\mathrm{pH}$ shift of the feed and a decrease of the conductivity before loading onto the column in order to optimize the dynamic binding capacity $[7,16]$. Older CEX processes distinguished themselves by a capacity of $20-30 \mathrm{~g} / \mathrm{L}$ which cannot cope with new increasing product titers [7]. Optimizations of the resin resulted in capacities as high as $100 \mathrm{~g} / \mathrm{L}$ at high flow rates und purity $[88,89,91,92]$. This technique can be used for antibodies with a basic isoelectric point [16]. Antibody variants, e.g., charge variants or aggregates, can be removed as well as most negatively charged impurities [16]. The costs of CEX are approximately one fifth of the costs for Protein A chromatography [7]. Synagis and Humira are two examples of commercially available mAbs which are purified by an application of CEX as capture step $[7,88]$.

Another alternative of Protein A chromatography are mimetic resins. The resins possess ligands which bind immunoglobulins (Ig) specifically and can potentially replace Protein A [90]. These can be Ig-binding proteins like protein $\mathrm{G}$ and $\mathrm{L}$, synthetic ligands, bioengineered peptides [90,93-95] or Protein A like porous polymeric monoliths [95]. Different approaches of Protein A mimicking are described by El Khoury et al. (2013) [93], Qian et al. (2012) [96], Roque et al. (2005) [97] and Teng et al. (2000) [98], among others. 
Subsequently, up to three chromatographic separations are applied in a classic manufacturing process. Ion exchange chromatography (IEC) is often used to reduce residual impurities including product variants, remaining HCP and DNA, leached Protein A, media components, endotoxins and virus from the cell line [16]. Anion as well as cation exchange chromatography can be run in flow-through or in bind-and-elute mode. They are often applied directly after Protein A Chromatography. Hydrophobic interaction chromatography (HIC) is complementary to ion exchange chromatography and Protein A and is mostly used as polishing step. In flow-through mode, HIC removes mostly aggregates, in bind-and-elute mode process- and product-related impurities [16]. These separations are significantly less expensive than Protein A chromatography but they are limited in capacity and throughput. Considering increasing product titers and new separation tasks, they have reached their limits $[11,16,99]$. Different optimization approaches regarding resins, operation modes or elution conditions are tested in order to avoid these limitations.

Optimization of a chromatography step includes the design of improved ligands and matrices. These improvements may allow shorter residence times, higher flow rates $[11,16,100]$ and longer life cycles. Future effort should be directed towards increased binding capacity at manufacturing scale, the number of cycles to process a harvested batch and the establishment of an intermediate washing step to remove remaining impurities [16,86]. Gagnon (2012) reviews different development trends regarding chromatography [4]. Another focus consists in connected processing including salt tolerant media or mixed-mode application [101-103]. To eliminate Protein A as the currently most expensive chromatographic step, lower-cost alternatives are under investigation. Possible alternatives are combinations of ion exchange and hydrophobic interaction chromatography [104].

\subsubsection{Non-Chromatographic Separations}

Further trends in DSP address the development of non-chromatographic operations such as membrane-based procedures [4,11,105], aqueous two-phase extraction (ATPE) [99,106-108], precipitation $[2,4,6,18]$, crystallization $[109,110]$ or affinity alternatives [11]. This trend aims to reduce or even eliminate chromatographic operations. Non-chromatographic separations are in many cases proven in non-pharmaceutical processes with much higher feed volumes. Therefore, they are particularly useful for DSP now that higher titers are involved and greater amounts of buffer are required. These "low-tech" separation methods are good for high-volume feeds and rapidly remove a lot of liquid. This development may allow a reduction of costs, process time and yield losses.

Membrane processes are one of the most important unit operations in biopharmaceutical processing. In USP, microfiltration membranes filtrate media, buffer and gases; in DSP they can be used as initial harvest operation for removal of biomass [16,105,111], particles prior to chromatographic operations and DNA from cell cultures [105]. Ultrafiltration membranes with a range of 1-100 nm are used to concentrate and diafilter biomolecules $[16,105]$. In order to ensure virus clearance, symmetric membranes are necessary with a narrow pore size distribution of 20-50 nm [105,111]. The separation mechanism is mainly based on molecular weight and to a lesser extent on shape and charge $[16,105,112]$. Other membranes frequently used are depth filters or high performance tangential flow membranes which can be neutral or charged [16,111]. Kumar et al. (2013) separated biomolecules based on their charge by charged ultrafiltration membranes [113,114]. 
The former function of membranes as selective barrier for filtration is extended towards a selective adsorption of molecules to separate them according to their chemical behavior $[2,102,105,115,116]$. This relatively new development in membrane technology is called membrane chromatography $[16,105,111]$. These are symmetric microfiltration membranes functionalized with specific ligands attached directly to the convective membrane pores $[16,105,111,117]$. Diffusive pores are eliminated, mass transfer of biomolecules depends on convection and the binding capacity is largely independent of flow rates [16]. Significant advances have recently been made in developing high permeability and high capacity sterile filters by application of composite membranes. Membrane adsorbers are used for polishing applications to remove contaminants [105,111]. Viruses, endotoxins DNA, HCP and leached Protein A binds to the membrane at neutral to slightly basic $\mathrm{pH}$ and low conductivity [16]. Additionally, salt-tolerant membrane adsorbers have been developed for viral clearance as well as HIC membranes which have comparable dynamic binding capacities to conventional HIC resins [111]. Other development trends investigate the possibility to apply membrane adsorber in capture and purification of large biomolecules and will focus on new designs of structures for bind-and-elute processes [105]. Other fields in need of optimization concern flow distribution, membrane size distribution and thickness [16].

Research activities on aqueous two-phase extraction (ATPE) show potential applications of this process for separation of cells and undissolved components, of impurities and product. ATPE is considered a simple and low-cost technology compared to Protein A chromatography. It has advantages in scalability, can be applied in continuous processes and has a high capacity [99,106-108]. Unfortunately, there is still a limited understanding of molecular mechanisms of ATPE [118]. Other downsides are difficulties regarding its use as a platform step due to complex interactions of the multiple components involved. Another problem might be a sensitivity to feed stream variability [11]. In spite of this, strategies for ATPE design and process implementation are being developed [118] and already applied in purification processes of recombinant proteins [119].

Precipitation can also be used for protein purification in industrial scale [106,120-122]. Current research indicates possible applications for product concentration and the separation of product and impurities. Volume limitations of the subsequent unit operation can be accommodated [120]. Membrane filtration removes the supernatant and is followed by dissolving the precipitate in a preferred buffer volume. This filtration process can be carried out either by dead-end filtration in lab-scale or by cross-flow filtration in industrial scale [4,123]. Centrifugation can be used as a substitute for filtration $[4,120]$. Another application of precipitation could be as a purification step before a capture by CEX. HCP and media components would be separated before a chromatographic capturing would take place [124]. Antibodies can be separated by either ammonium sulfate precipitation $[4,121,125]$ or co-precipitation with negatively charged polymers [4]. Another possible application consists in a co-precipitation of several impurities with positively charged polymers. Those impurities include acidic HCP, DNA, and residual media components [4,120,126].

Crystallization is mostly applied in protein structure analysis and is already used as a cost effective and scalable purification procedure for small molecules $[109,110]$. Examples are the purification of low molecular weight substances like amino acids or industrial enzymes [11], like industrial lipase, or ovalbumin [109,110]. In insulin purification, crystallization is applied as polishing step benefitting formulation aspects of higher stability [109]. Its application in antibody purification is limited due to their size and heterogeneity [11]. A possible establishment in the purification process could be 
performed inexpensively and with large volumes [110]. Crystallization would benefit formulation due to a higher stability of the final product in crystalline form [109]. It might be a suitable alternative to chromatography or ultra- and diafiltration $[109,110]$. However, this procedure is currently not ready for use. Only three recent studies presented potential $\mu 1$-scale crystallization of whole antibodies [110] and Smejkal et al. (2013) [110] reported a successful crystallization of an IgG1-type antibody in a stirred L-scale.

Other technologies for process development and integration include flocculation [106,127] and magnetic separations [11], among others.

A successful integration of new technologies into a separation sequence requires a lot of time and effort in process development. New methods, e.g., high-throughput-screening and/or modeling approaches, may be able to improve the manufacturing process. A standardization of a new unit operation, resulting in a reliable and robust operation which can be applied to other products, may allow its use as potential platform technology. This platform should be able to reduce time and effort in DSP development of other products significantly $[2,16,18,30]$.

\section{Critical Parameters in Process Development}

Current separation technologies in antibody purification are designed for feeds of $2-5 \mathrm{~g} / \mathrm{L}$ product concentration [6,8] which are routinely reached in generic fed-batch processes [128]. In USP, further optimizations are aiming to increase the product volumes significantly. Product concentrations of up to $25 \mathrm{~g} / \mathrm{L}$ were achieved by a two week long modified perfusion process of PER.C6 ${ }^{\circledR}$ [7,9]. Product titers of above $5 \mathrm{~g} / \mathrm{L}$ are going to exhaust existing capacities in DSP [2,7,18] and extensions of these capacities would shift the main costs of manufacturing towards DSP [7,8,10,11].

An increased antibody titer upstream requires a higher amount of chromatography resin, buffer and membranes downstream and consequently, costs scale. Strube et al. (2012) [10] presented studies on cost distributions in downstream processing depending on product concentrations. They show the shift of production costs towards DSP and a possible increase of costs of the overall manufacturing process in case of higher titer in USP development in future processes. Based on the assumption of a constant spectrum of impurities, the overall cost of goods (COG) decrease with increasing product titers. In contrast, downstream costs dominate the overall production costs with increasing titer. Assuming a change in the composition of impurities with increasing titers due to optimizations of cultivation parameters [12-16], the costs of DSP are significantly higher [10]. Considering the trend towards further increasing product titers in future processes, a similar trend of increasing costs is expected for downstream processing $[10,17,84]$.

\section{Impurities in Biopharmaceutical Manufacturing}

Impurities generally consist of product and process related components as well as contaminants [129]. Product related components are molecular variants of the desired target molecule [129], precursors, degraded products [130,131], aggregates or product variants by different posttranslational modification [131,132]. They arise from production or during storage and possess different properties compared to the product regarding activity, efficacy or safety aspects. Process related impurities are cell components like host cell proteins (HCP) or DNA, chemical additives, residual media 
components $[15,129,133]$ or leachables like Protein A [15]. Residual media components or digested components include carbohydrates, amino acids, vitamins, salts and lipids, among others. Contaminants include all adventitiously introduced materials which are not part of the manufacturing process, such as (bio-) chemical materials or microbial species. They should be strictly avoided [129].

Especially, host cell proteins (HCP) are a main source of impurities. This complex group of proteins is defined by their broad variety of properties. HCP of one process differ significantly from each other in their molecular mass, isoelectric point, hydrophobicity and structure. They can easily be a challenge for product purification due to the changing level, composition and property distribution during a single fermentation process.

Few studies have investigated problematic HCP and their removal in DSP. Pezzini et al. (2011) [101] monitored the fate of HCP through chromatographic operations. Low et al. (2007) [11] and Guiochon and Beaver (2011) [134] reported the HCP profiles in eluates from Protein A chromatography. Hogwood et al. (2013) [13] also reported the significant impact of harvest operations on the HCP profile. According to them, early DSP operations impact the HCP profile and the relative abundance of particular proteins throughout product purification.

HCP compositions depend strongly on metabolic pathways which are characteristic for the chosen cell line and clone and result in a characteristic pattern of proteins [14]. Other pathways are changed in order to optimize metabolic production routes of the product and thereby, changing production routes of secondary metabolic products $[14,135,136]$. Their composition depends on several factors: host organism [14], cell clone [137], protein of interest [136], route of metabolic expression [14,135], viability [12,137], stage of cell culture, process conditions in fermentation and harvest conditions [12].

Tait et al. (2012) [12] demonstrated the impact of age and viability of the cell culture on HCP composition. During the fermentation, cells produce different proteins at the end than they do in the beginning. This is due to changes in the environment and their metabolism. Additionally, the amount of HCP increases significantly at a stage of decreasing viability. Process conditions influence the HCP profile, too. According to Jin et al. (2010) [14] the HCP level can change by a factor of 0.5-7 due to variations of temperature, aeration, feeding strategy, medium composition, cell culture duration and harvest conditions, among others. The results of Tait et al. (2012) [12] indicate that the time of harvest is crucial towards the resulting spectrum of impurities which enters the downstream processing. Along these results, it should be investigated if an earlier harvest results in an easier separable HCP spectrum. This can improve the overall process in spite of a potential loss of production time.

The changes in levels of HCP, their composition and distribution of properties present a high optimization potential in bioprocess development. The high dependency of HCP profiles from different USP parameters is suitable as an optimization tool. By changing the focus of early upstream development, it is possible to reduce the HCP production or to influence its composition and improve DSP performance. By identification of unfavorable proteins in DSP, a screening for cell lines which produce HCP at lower levels would improve product purification [13].

\section{Trends in Process Development and Optimization Strategies}

Integration of different downstream operations will advance. An integration of ion exchange and hydrophobic interaction chromatography would, for example, permit the use of only one buffer system 
for both operations [104]. Further trends in purification technology include other non-chromatographic processes like membrane adsorbers [102,105], crystallization [109,110], precipitation or aqueous two-phase separation [99,106-108]. Predictive biopharmaceutical process design will gain importance in process development as well. Possible applications will result in cost reduction and improve the success rate of commercial viability [138]. In DSP, rigorous modeling is already established. Other approaches are developed regarding USP needs. For example, Kontoravdi et al. (2013) [139] presented an approach to model scale up and glycosylation behavior in USP of mAbs.

Another new approach consists in the application of quantitative structure-activity relationship (QSAR) modeling. Data analysis methods and statistics are applied to develop models that can accurately predict biological activities or properties of compounds based on their structures [140,141]. QSAR modeling might be able to predict the chromatographic separation of proteins [142]. One example was published by Buyel et al. (2013) [142]. They described the use of QSAR modeling to optimize chromatographic removal of tobacco host cell proteins in biopharmaceutical production.

Transient gene expression might be another interesting option in future manufacturing processes. It has already been established in process development in screening steps for possible proteins of interest. Its establishment as a manufacturing technology is going to require more effort on product titer, cell number, ensuring product quality [56] and industrial acceptance [25] but its application has significant potential to save time and therefore costs. An established transfection/expression process might allow running production campaigns for a diversity of different recombinant proteins, including antibodies, using one facility and one host cell line. It is likely to be significantly faster and more flexible. Girard et al. (2002) [57] presented a successful transient transfection on a $100 \mathrm{~L}$ scale.

The implementation of new separation technologies on an industrial scale will require significant investments in development, scale up and validation including associated risks. Therefore, they need to differentiate themselves by distinct increases in efficiency and cost reduction and should be evaluated carefully [8]. To reduce production volumes, the need for facility flexibility and faster turnarounds will increase. This can lead towards implementation of disposables in manufacturing $[2,80]$, continuous processing $[143,144]$ and dedicated but decentralized manufacturing concepts in containers [145].

Advances in single-use technology lead to its increased implementation in biopharmaceutical production in order to lower capital and operational costs, increase production flexibility and enable a rapid set-up of bioprocessing and progressive manufacture of multiple products [77]. Today, single-use product lines include devices from storage bags to bioreactors resulting in the possibility for a complete single-use upstream process [77]. Trends in development address limits in scale and scarcity of standardization and validation as well as interactions between the plastic bags and process components [80]. The possibilities of leachables and extractables need to be worked on as well. In DSP, it has been difficult and expensive to implement a fully single-use process up to now $[77,80]$. Recent advances achieved product-dedicated fixed columns and fully disposable columns [80]. Disposable membrane cassettes seem to be an appropriate alternative to flow-through chromatography steps [80]. Membrane adsorption technologies, single-use moving bed, countercurrent chromatography and other chromatography methods are likely to be implemented as single-use in coming years [77].

The limit in scale of disposable technologies results in considerations of alternatives in process strategies for fed-batch processes. Continuous processing in $\mathrm{mAb}$ manufacturing is one trend to be considered in the coming years. Vogel et al. (2012) [20] published a development strategy for a 
platform process based on continuous operations on a small scale including membrane adsorber for processing of complex biopharmaceuticals, however not antibodies. A transfer of this scheme to antibody purification would require membrane adsorber of a much higher capacity. Other options consist in the development of continuous operation modes of ATPE [107,146,147], centrifugation [148] or new continuous principles in chromatography, like MCSGP [149] or iCCC [150]. In upstream processing, continuous cultivations are already well established, as described before. Today, development trends concentrate on new cell retention devices and modifications of operation modes. The most interesting example in USP consists in a possible application of ATF as modified perfusion or concentrated fed-batch process $[66,67,69]$. In combination with continuous DSP and disposable technologies, it presents the opportunity to small-scale manufacturing processes of low investments costs and risks. In addition, the creation of high-volume cell banks could also be achieved resulting into a shortened bioreactor train in manufacturing processes [69].

In terms of capacity, it is most likely that current large facilities $(>10,000 \mathrm{~L})$ will remain. New capacities, however, will be added on a lower scale. Other products, for example individualized biologics and personalized medicines, will probably be produced in small scale using single-use technologies due to small required volumes. This trend is likely to advance towards modular facilities. Bioprocessing unit operations can be housed in container-like transportable clean rooms allowing the whole manufacturing process to be transported, constructed and operational within the shortest amount of time [77]. They also have the advantage of possible use in GMP-challenged countries.

Current optimization approaches are aimed at single unit operations within the overall manufacturing process. Optimizations between USP and DSP currently focus on titer, aggregates and, if required, isoforms. Turbidity may be another parameter as well. DNA content is considered by choosing an appropriate harvest operation which reduces possible cell damage to a minimum. Other impurities are seldom taken into account during process development. This is going to be a problem since steadily increasing product titers involve creating impurities which are more difficult to separate. In order to optimize the overall manufacturing process, it is necessary to take these impurities into account. The question is: Would it be better to produce less product in order to change the impurity profile towards less impurities or at least to create only impurities which are easy to separate? Such a concept might result in a less expensive manufacturing process due to reduced yield losses. This integration of upstream and downstream processing can be considered a first useful tool. It addresses this challenge regarding $\mathrm{HCP}$ and changes the focus of upstream development. Foci of media and process optimization need to be adapted as well as new selection strategies for cell lines, and cell clones have to be implemented. Data by the groups of Hogwood (2013) [13] and Liu (2009) [151] suggested that such a change of early process development in USP focusing on HCP should seriously be considered.

\section{Concluding Remarks and Outlook}

Demands for high quality biologics will continue to increase in the coming decades. However, the boundary conditions will change substantially. Amounts to be produced and the number of products will increase. Additionally, there will be less, or even no blockbusters due to a shift towards stratified medicine. Many of the current blockbusters will be "running out of patent" during the next years. 
In combination with increasing pressure from regulatory agencies for enhanced quality and lower process costs from the health care systems, we are facing a major challenge.

The trend towards stratified therapeutics will support a change in plant design aiming for highly flexible multi-purpose facilities for small production volumes. Such a development will not only push innovation in the development of single-use technologies but also in the development of non-chromatographic, continuous and flexible downstream operations. As one consequence of these changes in process development, an integration of USP and DSP development regarding impurity profiles would be useful as a supporting tool for process optimization which can be established at reasonable expense.

\section{Acknowledgments}

The Authors would like to thank Jan Eggersglüß (now Boehringer Ingelheim, Biberach).

\section{Conflicts of Interest}

The authors declare no conflict of interest.

\section{References}

1. Jain, E.; Kumar, A. Upstream processes in antibody production: Evaluation of critical parameters. Biotechnol. Adv. 2008, 26, 46-72.

2. Shukla, A.A.; Thömmes, J. Recent advances in large-scale production of monoclonal antibodies and related proteins. Trends Biotechnol. 2010, 28, 253-261.

3. Elvin, J.G.; Couston, R.G.; van der Walle, Christopher F. Therapeutic antibodies: Market considerations, disease targets and bioprocessing. Int. J. Pharm. 2013, 440, 83-98.

4. Gagnon, P. Technology trends in antibody purification. J. Chromatogr. A 2012, 1221, 57-70.

5. Li, F.; Vijayasankaran, N.; Shen, A.; Kiss, R.; Amanullah, A. Cell culture processes for monoclonal antibody production. Pharm. Sci. Encycl. 2010, 2, 466-479.

6. Kelley, B. Very large scale monoclonal antibody purification: The case for conventional unit operations. Biotechnol. Progr. 2007, 23, 995-1008.

7. Chon, J.H.; Zarbis-Papastoitsis, G. Advances in the production and downstream processing of antibodies. New Biotechnol. 2011, 28, 458-463.

8. Kelley, B. Industrialization of $\mathrm{mAb}$ production technology: The bioprocessing industry at a crossroads. MAbs 2009, 1, 443-452.

9. Butler, M.; Meneses-Acosta, A. Recent advances in technology supporting biopharmaceutical production from mammalian cells. Appl. Microbiol. Biotechnol. 2012, 96, 885-894.

10. Strube, J.; Grote, F.; Ditz, R. Bioprocess Design and Production Technology for the Future. In Biopharmaceutical Production Technology, 1st ed.; Subramanian, G., Ed.; Wiley-VCH: Weinheim, Germany, 2012; Volume 2.

11. Low, D.; O'Leary, R.; Pujar, N.S. Future of antibody purification. J. Chromatogr. B 2007, 848, 48-63. 
12. Tait, A.S.; Hogwood, C.E.M.; Smales, C.M.; Bracewell, D.G. Host cell protein dynamics in the supernatant of a mAb producing CHO cell line. Biotechnol. Bioeng. 2012, 109, 971-982.

13. Hogwood, C.E.M.; Tait, A.S.; Koloteva-Levine, N.; Bracewell, D.G.; Smales, C. Mark the dynamics of the $\mathrm{CHO}$ host cell protein profile during clarification and protein A capture in a platform antibody purification process. Biotechnol. Bioeng. 2013, 110, 240-251.

14. Jin, M.; Szapiel, N.; Zhang, J.; Hickey, J.; Ghose, S. Profiling of host cell proteins by two-dimensional difference gel electrophoresis (2D-DIGE): Implications for downstream process development. Biotechnol. Bioeng. 2010, 105, 306-316.

15. Tscheliessnig, A.L.; Konrath, J.; Bates, R.; Jungbauer, A. Host cell protein analysis in therapeutic protein bioprocessing-Methods and applications. Biotechnol. J. 2013, 8, 655-670.

16. Liu, H.F.; Ma, J.; Winter, C.; Bayer, R. Recovery and purification process development for monoclonal antibody production. MAbs 2010, 2, 480-499.

17. Birch, J.R.; Racher, A.J. Antibody production. Adv. Drug Deliver Rev. 2006, 58, 671-685.

18. Shukla, A.A.; Hubbard, B.; Tressel, T.; Guhan, S.; Low, D. Downstream processing of monoclonal antibodies-Application of platform approaches. J. Chromatogr. B 2007, 848, 28-39.

19. Nfor, B.K.; Verhaert, P.D.E.M.; van der Wielen, L.A.M.; Hubbuch, J.; Ottens, M. Rational and systematic protein purification process development: The next generation. Trends Biotechnol. 2009, 27, 673-679.

20. Vogel, J.H.; Nguyen, H.; Giovanni, R.; Ignowski, J.; Garger, S.; Salgotra, A.; Tom, J. A new large-scale manufacturing platform for complex biopharmaceuticals. Biotechnol. Bioeng. 2012, 109, 3049-3058.

21. Bhambure, R.; Kumar, K.; Rathore, A.S. High-throughput process development for biopharmaceutical drug substances. Trends Biotechnol. 2011, 29, 127-135.

22. Amanullah, A.; Otero, J.M.; Mikola, M.; Hsu, A.; Zhang, J.; Aunins, J.; Schreyer, H.B.; Hope, J.A.; Russo, A.P. Novel micro-bioreactor high throughput technology for cell culture process development: Reproducibility and scalability assessment of fed-batch CHO cultures. Biotechnol. Bioeng. 2010, 106, 57-67.

23. De Jesus, Maria J; Girard, P.; Bourgeois, M.; Baumgartner, G.; Jacko, B.; Amstutz, H.; Wurm, F.M. TubeSpin satellites: A fast track approach for process development with animal cells using shaking technology. Biochem. Eng. J. 2004, 17, 217-223.

24. Bareither, R.; Bargh, N.; Oakeshott, R.; Watts, K.; Pollard, D. Automated disposable small scale reactor for high throughput bioprocess development: A proof of concept study. Biotechnol. Bioeng. 2013, 110, 3126-3138.

25. De Jesus, Maria; Wurm, F.M. Manufacturing recombinant proteins in kg-ton quantities using animal cells in bioreactors. Eur. J. Pharm Biopharm. 2011, 78, 184-188.

26. Jordan, M.; Voisard, D.; Berthoud, A.; Tercier, L.; Kleuser, B.; Baer, G.; Broly, H. Cell culture medium improvement by rigorous shuffling of components using media blending. Cytotechnology 2013, 65, 31-40.

27. Zhang, H.; Wang, H.; Liu, M.; Zhang, T.; Zhang, J.; Wang, X.; Xiang, W. Rational development of a serum-free medium and fed-batch process for a GS-CHO cell line expressing recombinant antibody. Cytotechnology 2013, 65, 363-378. 
28. Sen, S.; Roychoudhury, P. Development of optimal medium for production of commercially important monoclonal antibody 520C9 by hybridoma cell. Cytotechnology 2013, 65, 233-252.

29. Jiang, Z.; Droms, K.; Geng, Z.; Casnocha, S.; Xiao, Z.; Gorfien, S. Fed-batch cell culture process optimization. A rationally integrated approach. BioProcess Int. 2012, 10, 40-45.

30. Heckathorn, R.; Adams, D.; Hunter, J.; Frieden, E. Increasing Upstream Process Development Efficiency by Implementing Platform Glutamine Synthetase Cell Culture Processes. In Cells and Culture; Noll, T., Ed.; Springer Netherlands: Heidelberg, Germany, 2010; pp. 245-251.

31. Castro, P.L.; Hayter, P.; Ison, A.; Bull, A. Application of a statistical design to the optimization of culture medium for recombinant interferon-gamma production by Chinese hamster ovary cells. Appl. Microbiol. Biotechnol. 1992, 38, 84-90.

32. Hammett, K.; Kuchibhatla, J.; Hunt, C.; Holdread, S.; Brooks, J. Developing Chemically Defined Media through DOE: Complete Optimization with Increased Protein Production in Less than 8 Months. In Cell Technology for Cell Products; Smith, R., Ed.; Springer Netherlands: Heidelberg, Germany, 2007; pp. 683-691.

33. Michels, D.A.; Parker, M.; Salas-Solano, O. Quantitative impurity analysis of monoclonal antibody size heterogeneity by CE-LIF: Example of development and validation through a quality-by-design framework. Electrophoresis 2012, 33, 815-826.

34. Pathak, M.; Dutta, D.; Rathore, A. Analytical QbD: Development of a native gel electrophoresis method for measurement of monoclonal antibody aggregates. Electrophoresis 2014, 35, 2163-2171.

35. Jiang, C.; Flansburg, L.; Ghose, S.; Jorjorian, P.; Shukla, A.A. Defining process design space for a hydrophobic interaction chromatography (HIC) purification step: Application of quality by design (QbD) principles. Biotechnol. Bioeng. 2010, 107, 985-997.

36. Del Val, I.J.; Kontoravdi, C.; Nagy, J.M. Towards the implementation of quality by design to the production of therapeutic monoclonal antibodies with desired glycosylation patterns. Biotechnol. Prog. 2010, 26, 1505-1527.

37. Martin-Moe, S.; Lim, F.J.; Wong, R.L.; Sreedhara, A.; Sundaram, J.; Sane, S.U. A new roadmap for biopharmaceutical drug product development: Integrating development, validation, and quality by design. J. Pharm Sci. 2011, 100, 3031-3043.

38. Rathore, A.S. Roadmap for implementation of quality by design (QbD) for biotechnology products. Trends Biotechnol. 2009, 27, 546-553.

39. Horvath, B.; Mun, M.; Laird, M. Characterization of a monoclonal antibody cell culture production process using a quality by design approach. Mol. Biotechnol. 2010, 45, 203-206.

40. Harms, J.; Wang, X.; Kim, T.; Yang, X.; Rathore, A. Defining process design space for biotech products: Case study of pichia pastoris fermentation. Biotechnol. Prog. 2008, 24, 655-662.

41. Abu-Absi, S.F.; Yang, L.; Thompson, P.; Jiang, C.; Kandula, S.; Schilling, B.; Shukla, A.A. Defining process design space for monoclonal antibody cell culture. Biotechnol. Bioeng. 2010, 106, 894-905.

42. Yang, S.-T.; Kiu, X. Cell culture processes for biologics manufacturing: Recent developments and trends. Pharm. Bioprocess. 2013, 1, 133-136.

43. Rita Costa, A.; Elisa Rodrigues, M.; Henriques, M.; Azeredo, J.; Oliveira, R. Guidelines to cell engineering for monoclonal antibody production. Eur. J. Pharm Biopharm. 2010, 74, 127-138. 
44. Zhu, J. Mammalian cell protein expression for biopharmaceutical production. Biotechnol. Adv. 2012, 30, 1158-1170.

45. Jayapal, K.P.; Wlaschin, K.F.; Hu, W.; Yap, M.G. Recombinant protein therapeutics from CHO cells-20 years and counting. Chem. Eng. Prog. 2007, 103, 40-47.

46. Durocher, Y.; Butler, M. Expression systems for therapeutic glycoprotein production. Curr. Opin. Biotech. 2009, 20, 700-707.

47. Hossler, P.; Khattak, S.F.; Li, Z.J. Optimal and consistent protein glycosylation in mammalian cell culture. Glycobiology 2009, 19, 936-949.

48. Kanda, Y.; Imai-Nishiya, H.; Kuni-Kamochi, R.; Mori, K.; Inoue, M.; Kitajima-Miyama, K.; Okazaki, A.; Iida, S.; Shitara, K.; Satoh, M. Establishment of a GDP-mannose 4,6-dehydratase (GMD) knockout host cell line: A new strategy for generating completely non-fucosylated recombinant therapeutics. J. Biotechnol. 2007, 130, 300-310.

49. Mori, K.; Kuni-Kamochi, R.; Yamane-Ohnuki, N.; Wakitani, M.; Yamano, K.; Imai, H.; Kanda, Y.; Niwa, R.; Iida, S.; Uchida, K.; Shitara, K.; Satoh, M. Engineering Chinese hamster ovary cells to maximize effector function of produced antibodies using FUT8 siRNA. Biotechnol. Bioeng. 2004, 88, 901-908.

50. Kim, S.; Lee, G. Down-regulation of lactate dehydrogenase-A by siRNAs for reduced lactic acid formation of Chinese hamster ovary cells producing thrombopoietin. Appl. Microbiol. Biotechnol. 2007, 74, 152-159.

51. Chen, K.; Liu, Q.; Xie, L.; Sharp, P.A.; Wang, D.I.C. Engineering of a mammalian cell line for reduction of lactate formation and high monoclonal antibody production. Biotechnol. Bioeng. 2001, 72, 55-61.

52. Jeong, D.-W.; Cho, I.; Kim, T.; Bae, G.; Kim, I.-H.; Kim, I. Effects of lactate dehydrogenase suppression and glycerol-3-phosphate dehydrogenase overexpression on cellular metabolism. Mol. Cell. Biochem. 2006, 284, 1-8.

53. Sauerwald, T.M.; Figueroa, B.; Hardwick, J.M.; Oyler, G.A.; Betenbaugh, M.J. Combining caspase and mitochondrial dysfunction inhibitors of apoptosis to limit cell death in mammalian cell cultures. Biotechnol. Bioeng. 2006, 94, 362-372.

54. Lee, C.J.; Seth, G.; Tsukuda, J.; Hamilton, R.W. A clone screening method using mRNA levels to determine specific productivity and product quality for monoclonal antibodies. Biotechnol. Bioeng. 2009, 102, 1107-1118.

55. Noh, S.M.; Sathyamurthy, M.; Lee, G.M. Development of recombinant Chinese hamster ovary cell lines for therapeutic protein production. Curr. Opin. Chem. Eng. 2013, 2, 391-397.

56. Baldi, L.; Hacker, D.L.; Adam, M.; Wurm, F.M. Recombinant protein production by large-scale transient gene expression in mammalian cells: State of the art and future perspectives. Biotechnol. Lett. 2007, 29, 677-684.

57. Girard, P.; Derouazi, M.; Baumgartner, G.; Bourgeois, M.; Jordan, M.; Jacko, B.; Wurm, F.M. 100-liter transient transfection. Cytotechnology 2002, 38, 15-21.

58. Rajendra, Y.; Kiseljak, D.; Baldi, L.; Hacker, D.L.; Wurm, F.M. A simple high-yielding process for transient gene expression in CHO cells. J. Biotechnol. 2011, 153, 22-26.

59. Fletcher, T. Designing culture media for recombinant protein production: A rational approach. BioProcess Int. 2005, 3, 30-36. 
60. Kim, S.; Lee, G. Development of serum-free medium supplemented with hydrolysates for the production of therapeutic antibodies in $\mathrm{CHO}$ cell cultures using design of experiments. Appl. Microbiol. Biotechnol. 2009, 83, 639-648.

61. Lu, F.; Toh, P.C.; Burnett, I.; Li, F.; Hudson, T.; Amanullah, A.; Li, J. Automated dynamic fed-batch process and media optimization for high productivity cell culture process development. Biotechnol. Bioeng. 2013, 110, 191-205.

62. Ma, N.; Ellet, J.; Okediadi, C.; Hermes, P.; McCormick, E.; Casnocha, S. A single nutrient feed supports both chemically defined NSO and CHO fed-batch processes: Improved productivity and lactate metabolism. Biotechnol. Prog. 2009, 25, 1353-1363.

63. Zhou, W.; Chen, C.-C.; Buckland, B.; Aunins, J. Fed-batch culture of recombinant NS0 myeloma cells with high monoclonal antibody production. Biotechnol. Bioeng. 1997, 55, 783-792.

64. Voisard, D.; Meuwly, F.; Ruffieux, P.-A.; Baer, G.; Kadouri, A. Potential of cell retention techniques for large-scale high-density perfusion culture of suspended mammalian cells. Biotechnol. Bioeng. 2003, 82, 751-765.

65. Henzler, H.-J. Kontinuierliche Fermentation mit tierischen Zellen. Teil 1. Aspekte der kontinuierlichen Prozessführung. Chem. Ing. Tech. 2012, 84, 1469-1481.

66. Clincke, M.-F.; Mölleryd, C.; Samani, P.K.; Lindskog, E.; Fäldt, E.; Walsh, K.; Chotteau, V. Very high density of Chinese hamster ovary cells in perfusion by alternating tangential flow or tangential flow filtration in WAVE Bioreactor ${ }^{\mathrm{TM}}$-part II: Applications for antibody production and cryopreservation. Biotechnol. Prog. 2013, 29, 768-777.

67. Clincke, M.-F.; Mölleryd, C.; Zhang, Y.; Lindskog, E.; Walsh, K.; Chotteau, V. Very high density of $\mathrm{CHO}$ cells in perfusion by ATF or TFF in WAVE bioreactor ${ }^{\mathrm{TM}}$. Part I. Effect of the cell density on the process. Biotechnol. Prog. 2013, 29, 754-767.

68. Pollock, J.; Ho, S.V.; Farid, S.S. Fed-batch and perfusion culture processes: Economic, environmental, and operational feasibility under uncertainty. Biotechnol. Bioeng. 2013, 110, 206-219.

69. Bonham-Carter, J.; Shevitz, J. A brief history of perfusion biomanufacturing. BioProcess Int. 2011, 9, 24-32.

70. Castilho, L.R.; Anspach, F.B.; Deckwer, W.-D. An integrated process for mammalian cell perfusion cultivation and product purification using a dynamic filter. Biotechnol. Prog. 2002, 18, 776-781.

71. Henzler, H.-J. Kontinuierliche Fermentation mit tierischen Zellen. Teil 2. Techniken und Methoden der Zellrückhaltung. Chem. Ing. Tech. 2012, 84, 1482-1496.

72. Gomez, N.; Ouyang, J.; Nguyen, M.D.H.; Vinson, A.R.; Lin, A.A.; Yuk, I.H. Effect of temperature, $\mathrm{pH}$, dissolved oxygen, and hydrolysate on the formation of triple light chain antibodies in cell culture. Biotechnol. Prog. 2010, 26, 1438-1445.

73. Jing, Y.; Borys, M.; Nayak, S.; Egan, S.; Qian, Y.; Pan, S.-H.; Li, Z.J. Identification of cell culture conditions to control protein aggregation of IgG fusion proteins expressed in Chinese hamster ovary cells. Process. Biochem. 2012, 47, 69-75.

74. Ye, J.; Kober, V.; Tellers, M.; Naji, Z.; Salmon, P.; Markusen, J.F. High-level protein expression in scalable CHO transient transfection. Biotechnol. Bioeng. 2009, 103, 542-551. 
75. Diekmann, S.; Dürr, C.; Herrmann, A.; Lindner, I.; Jozic, D. Single use bioreactors for the clinical production of monoclonal antibodies-A study to analyze the performance of a $\mathrm{CHO}$ cell line and the quality of the produced monoclonal antibody. BMC Proc. 2011, 5 (Suppl. 8), doi:10.1186/1753-6561-5-S8-P103.

76. Whitford, W.G. Single-use systems as principal components in bioproduction. BioProcess Int. 2010, 8, 34-42.

77. Langer, E.S.; Rader, R.A. Single-use technologies in biopharmaceutical manufacturing: A 10-year review of trends and the future. Eng. Life Sci. 2014, 14, 238-243.

78. Minow, B.; Seidemann, J.; Tschoepe, S.; Gloeckner, A.; Neubauer, P. Harmonization and characterization of different single-use bioreactors adopting a new sparger design. Eng. Life Sci. 2014, 14, 272-282.

79. Löffelholz, C.; Husemann, U.; Greller, G.; Meusel, W.; Kauling, J.; Ay, P.; Kraume, M.; Eibl, R.; Eibl, D. Bioengineering parameters for single-use bioreactors: Overview and evaluation of suitable methods. Chem. Ing. Tech. 2013, 85, 40-56.

80. Shukla, A.A.; Gottschalk, U. Single-use disposable technologies for biopharmaceutical manufacturing. Trends Biotechnol. 2013, 31, 147-154.

81. Reclari, M.; Dreyer, M.; Tissot, S.; Obreschkow, D.; Wurm, F.M.; Farhat, M. Surface wave dynamics in orbital shaken cylindrical containers. Phys. Fluids 2014, 26, doi:10.1063/1.4874612.

82. Wurm, F.M. Production of recombinant protein therapeutics in cultivated mammalian cells. Nat. Biotech. 2004, 22, 1393-1398.

83. Gottschalk, U. Process Scale Purification of Antibodies: Downstream Processing of Monoclonal Antibodies: Current Practices and Future Opportunities, 1st ed.: John Wiley \& Sons Inc.: Hoboken, NJ, USA, 2009.

84. Sommerfeld, S.; Strube, J. Challenges in biotechnology production-Generic processes and process optimization for monoclonal antibodies. Chem. Eng. Process. 2005, 44, 1123-1137.

85. Shukla, A.A.; Hinckley, P. Host cell protein clearance during protein A chromatography: Development of an improved column wash step. Biotechnol. Prog. 2008, 24, 1115-1121.

86. Tarrant, R.D.R.; Velez-Suberbie, M.L.; Tait, A.S.; Smales, C.M.; Bracewell, D.G. Host cell protein adsorption characteristics during protein A chromatography. Biotechnol. Prog. 2012, 28, 1037-1044.

87. Royce, J. High-capacity protein A chromatography medium for MAb coapture from high-titer feedds. BioProcess Int. 2014, 12, 40-41.

88. Lain, B.; Cacciuttolo, M.A.; Zarbis-Papastoitsis, G. Development of a high-capacity Mab capture step based on cation-exchange chromatography. BioProcess Int. 2009, 26-34.

89. Lain, B. Protein A: The life of disruptive technology. BioProcess Int. 2013, 11, 29-38.

90. Ghose, S.; Hubbard, B.; Cramer, S.M. Evaluation and comparison of alternatives to Protein A chromatography: Mimetic and hydrophobic charge induction chromatographic stationary phases. J. Chromatogr. A 2006, 1122, 144-152.

91. Gagnon, P. How to choose an industrial cation exchanger for IgG purification. BioProcess Int. 2010, 8, 22-34.

92. Jackewitz, A. Reducing elution volumes with high capacity and improved mass transfer ion-exchange resins. BioProcess Int. 2008, 6, 108-110. 
93. El Khoury, G.; Lowe, C.R. A biomimetic Protein G affinity adsorbent: An Ugi ligand for immunoglobulins and Fab fragments based on the third IgG-binding domain of Protein G. J. Mol. Recognit. 2013, 26, 190-200.

94. Arakawa, T.; Kita, Y.; Sato, H.; Ejima, D. MEP chromatography of antibody and Fc-fusion protein using aqueous arginine solution. Protein Expres. Purif. 2009, 63, 158-163.

95. Liu, Y.; Lu, Y.; Liu, Z. Restricted access boronate affinity porous monolith as a protein A mimetic for the specific capture of immunoglobulin G. Chem. Sci. 2012, 3, 1467-1471.

96. Qian, J.; El Khoury, G.; Issa, H.; Al-Qaoud, K.; Shihab, P.; Lowe, C.R. A synthetic Protein G adsorbent based on the multi-component Ugi reaction for the purification of mammalian immunoglobulins. J. Chromatogr. B. 2012, 898, 15-23.

97. Roque, A.C.A.; Taipa, M.Â.; Lowe, C.R. An artificial protein L for the purification of immunoglobulins and Fab fragments by affinity chromatography. J. Chromatogr. A 2005, 1064, $157-167$.

98. Teng, S.F.; Sproule, K.; Husain, A.; Lowe, C.R. Affinity chromatography on immobilized "biomimetic" ligands: Synthesis, immobilization and chromatographic assessment of an immunoglobulin G-binding ligand. J. Chromatogr. B 2000, 740, 1-15.

99. Azevedo, A.M.; Rosa, P.A.J.; Ferreira, I.F.; Aires-Barros, M. Raquel chromatography-free recovery of biopharmaceuticals through aqueous two-phase processing. Trends Biotechnol. 2009, 27, 240-247.

100. Hober, S.; Nord, K.; Linhult, M. Protein A chromatography for antibody purification. J. Chromatogr. B 2007, 848, 40-47.

101. Pezzini, J.; Joucla, G.; Gantier, R.; Toueille, M.; Lomenech, A.-M.; Le Sénéchal, C.; Garbay, B.; Santarelli, X.; Cabanne, C. Antibody capture by mixed-mode chromatography: A comprehensive study from determination of optimal purification conditions to identification of contaminating host cell proteins. J. Chromatogr. A 2011, 1218, 8197-8208.

102. Fischer-Fruhholz, S.; Zhou, D.; Hirai, M. Sartobind STIC ${ }^{\circledR}$ salt-tolerant membrane chromatography. Nat. Meth. 2010, 7, an12-an13.

103. Toueille, M.; Uzel, A.; Depoisier, J.-F.; Gantier, R. Designing new monoclonal antibody purification processes using mixed-mode chromatography sorbents. J. Chromatogr. B 2011, 879, 836-843.

104. Helling, C.; Borrmann, C.; Strube, J. optimal integration of directly combined hydrophobic interaction and ion exchange chromatography purification processes. Chem. Eng. Technol. 2012, 35, 1786-1796.

105. Fröhlich, H.; Villian, L.; Melzner, D.; Strube, J. Membrane technology in bioprocess science. Chem. Ing. Tech. 2012, 84, 905-917.

106. Rosa, P.A.J.; Ferreira, I.F.; Azevedo, A.M.; Aires-Barros, M.R. Aqueous two-phase systems: A viable platform in the manufacturing of biopharmaceuticals. J. Chromatogr. A 2010, 1217, 2296-2305.

107. Rosa, P.A.J.; Azevedo, A.M.; Sommerfeld, S.; Bäcker, W.; Aires-Barros, M.R. Continuous aqueous two-phase extraction of human antibodies using a packed column. J. Chromatogr. B 2012, 880, 148-156. 
108. Eggersgluess, J.; Both, S.; Strube, J. Process development for extraction of biomolecules. Application downstream processing of proteins in aqueous two-phase systems. Chem. Today 2012, 30, 32-36.

109. Zang, Y.; Kammerer, B.; Eisenkolb, M.; Lohr, K.; Kiefer, H. Towards protein crystallization as a process step in downstream processing of therapeutic antibodies: Screening and optimization at microbatch scale. PLoS ONE 2011, 6, doi:10.1371/journal.pone.0025282.

110. Smejkal, B.; Agrawal, N.; Helk, B.; Schulz, H.; Giffard, M.; Mechelke, M.; Ortner, F.; Heckmeier, P.; Trout, B.; Hekmat, D. Fast and scalable purification of a therapeutic full-length antibody based on process crystallization. Biotechnol. Bioeng. 2013, 110, 2452-2461.

111. Cramer, S.M.; Holstein, M.A. Downstream bioprocessing: Recent advances and future promise. Curr. Opin. Chem. Eng. 2011, 1, 27-37.

112. Saxena, A.; Tripathi, B.P.; Kumar, M.; Shahi, V.K. Membrane-based techniques for the separation and purification of proteins: An overview. Adv. Colloid Interfac. 2009, 145, 1-22.

113. Kumar, M.; Ulbricht, M. Advanced ultrafiltration membranes based on functionalized poly(arylene ether sulfone) block copolymers. RSC Adv. 2013, 3, 12190-12203.

114. Kumar, M.; Ulbricht, M. Novel ultrafiltration membranes with adjustable charge density based on sulfonated poly(arylene ether sulfone) block copolymers and their tunable protein separation performance. Polymer 2014, 55, 354-365.

115. Chenette, H.C.S.; Robinson, J.R.; Hobley, E.; Husson, S.M. Development of high-productivity, strong cation-exchange adsorbers for protein capture by graft polymerization from membranes with different pore sizes. J. Membrane Sci. 2012, 423-424, 43-52.

116. Weaver, J.; Husson, S.M.; Murphy, L.; Wickramasinghe, S.R. Anion exchange membrane adsorbers for flow-through polishing steps: Part II. Virus, host cell protein, DNA clearance, and antibody recovery. Biotechnol. Bioeng. 2013, 110, 500-510.

117. Drioli, E.; Stankiewicz, A.I.; Macedonio, F. Membrane engineering in process intensificationAn overview. J. Membrane Sci. 2011, 380, 1-8.

118. Benavides, J.; Aguilar, O.; Lapizco-Encinas, B.H.; Rito-Palomares, M. Extraction and purification of bioproducts and nanoparticles using aqueous two-phase systems strategies. Chem. Eng. Technol. 2008, 31, 838-845.

119. Somani, S.; Padmanabhan, S. Process for Purification of Recombinant Human Granulocyte Colony Stimulating Factor. U.S. Patent App. 13/378,973, 2010.

120. Giese, G.; Myrold, A.; Gorrell, J.; Persson, J. Purification of antibodies by precipitating impurities using Polyethylene Glycol to enable a two chromatography step process. J. Chromatogr. B 2013, 938, 14-21.

121. Oelmeier, S.A.; Ladd-Effio, C.; Hubbuch, J. Alternative separation steps for monoclonal antibody purification: Combination of centrifugal partitioning chromatography and precipitation. J. Chromatogr. A 2013, 1319, 118-126.

122. Kuczewski, M.; Schirmer, E.; Lain, B.; Zarbis-Papastoitsis, G. A single-use purification process for the production of a monoclonal antibody produced in a PER.C6 human cell line. Biotechnol. J. 2011, 6, 56-65. 
123. McDonald, P.; Victa, C.; Carter-Franklin, J.N.; Fahrner, R. Selective antibody precipitation using polyelectrolytes: A novel approach to the purification of monoclonal antibodies. Biotechnol. Bioeng. 2009, 102, 1141-1151.

124. Kuczewski, M.; Schirmer, E.; Lain, B. PEG precipitation: A powerful tool for Monoclonal Antibody Purification. Available online: http://www.biopharminternational.com (accessed on 1 August 2014).

125. Grodzki, A.; Berenstein, E. Antibody purification: Ammonium sulfate fractionation or gel filtration. Methods Mol. Biol. 2010, 588, 15-26.

126. Ma, J.; Hoang, H.; Myint, T.; Peram, T.; Fahrner, R.; Chou, J. Using precipitation by polyamines as an alternative to chromatographic separation in antibody purification processes. J. Chromatogr. B 2010, 878, 798-806.

127. Buyel, J.F.; Fischer, R. Flocculation increases the efficacy of depth filtration during the downstream processing of recombinant pharmaceutical proteins produced in tobacco. Plant. Biotechnol. J. 2014, 12, 240-252.

128. Fan, L.; Zhao, L.; Sun, Y.; Kou, T.; Zhou, Y.; Tan, W.-S. A high-yielding, generic fed-batch process for recombinant antibody production of GS-engineered cell lines. J. Microbiol. Biotechnol. 2009, 19, 1695-1702.

129. Food and Drug Administration. Federal Register/Vol. 63, No. 110/Tuesday, June 9, 1998/Notices, 1998. Available online: http://www.gpo.gov/fdsys/pkg/FR-1998-06-09/pdf/98-15195.pdf (accessed on 1 August 2014).

130. Raijada, D.K.; Prasad, B.; Paudel, A.; Shah, R.P.; Singh, S. Characterization of degradation products of amorphous and polymorphic forms of clopidogrel bisulphate under solid state stress conditions. J. Pharma. Biomed. 2010, 52, 332-344.

131. Pan, C.; Liu, F.; Motto, M. Identification of pharmaceutical impurities in formulated dosage forms. J. Pharm Sci. 2011, 100, 1228-1259.

132. Mazur, M.; Seipert, R.; Mahon, D.; Zhou, Q.; Liu, T. A platform for characterizing therapeutic monoclonal antibody breakdown products by 2D chromatography and top-down mass spectrometry. AAPS J. 2012, 14, 530-541.

133. Horak, J.; Ronacher, A.; Lindner, W. Quantification of immunoglobulin G and characterization of process related impurities using coupled Protein A and size exclusion high performance liquid chromatography. J. Chromatogr. A 2010, 1217, 5092-5102.

134. Guiochon, G.; Beaver, L.A. Separation science is the key to successful biopharmaceuticals. J. Chromatogr. A 2011, 1218, 8836-8858.

135. Wang, X.; Hunter, A.K.; Mozier, N.M. Host cell proteins in biologics development: Identification, quantitation and risk assessment. Biotechnol. Bioeng. 2009, 103, 446-458.

136. Prieto, Y.; Rojas, L.; Pérez, R. Towards the molecular characterization of the stable producer phenotype of recombinant antibody-producing NS0 myeloma cells. Cytotechnology 2011, 63, 351-362.

137. Grzeskowiak, J.K.; Tscheliessnig, A.; Wu, M.W.; Toh, P.C.; Chusainow, J.; Lee, Y.Y.; Wong, N.; Jungbauer, A. Two-dimensional difference fluorescence gel electrophoresis to verify the scale-up of a non-affinity-based downstream process for isolation of a therapeutic recombinant antibody. Electrophoresis 2010, 31, 1862-1872. 
138. Ditz, R. Separation Technologies 2030-Are 100 Years of Chromatography Enough? Chem. Ing. Tech. 2012, 84, 875-879.

139. Kontoravdi, C.; Samsatli, N.J.; Shah, N. Development and design of bio-pharmaceutical processes. Curr. Opin. Chem. Eng. 2013, 2, 435-441.

140. Kruhlak, N.L.; Benz, R.D.; Zhou, H.; Colatsky, T.J. (Q)SAR modeling and safety assessment in regulatory review. Clin. Pharmacol. Ther. 2012, 91, 529-534.

141. Tropsha, A. Best practices for QSAR model development, validation, and exploitation. Mol. Inf. 2010, 29, 476-488.

142. Buyel, J.F.; Woo, J.A.; Cramer, S.M.; Fischer, R. The use of quantitative structure-activity relationship models to develop optimized processes for the removal of tobacco host cell proteins during biopharmaceutical production. J. Chromatogr. A 2013, 1322, 18-28.

143. Konstantinov, K. Continous bioprocessing: An interview with Konstantin Konstantinov from Genzyme. Interviewed by Prof. Alois Jungbauer and Dr. Judy Peng. Biotechnol. J. 2011, 6, $1431-1433$.

144. Warikoo, V.; Godawat, R.; Brower, K.; Jain, S.; Cummings, D.; Simons, E.; Johnson, T.; Walther, J.; Yu, M.; Wright, B.; McLarty, J.; Karey, K.P.; Hwang, C.; Zhou, W.; Riske, F.; Konstantinov, K. Integrated continuous production of recombinant therapeutic proteins. Biotechnol. Bioeng. 2012, 109, 3018-3029.

145. Strube, J.; Ditz, R.; Fröhlich, H.; Köster, D.; Grützner, T.; Koch, J.; Schütte, R. Efficient engineering and production concepts for products in regulated environments-Dream or nightmare? Chem. Ing. Tech. 2014, 86, 687-694.

146. Asenjo, J.A.; Andrews, B.A. Aqueous two-phase systems for protein separation: Phase separation and applications. J. Chromatogr. A 2012, 1238, 1-10.

147. Rosa, P.A.J.; Azevedo, A.M.; Sommerfeld, S.; Mutter, M.; Bäcker, W.; Aires-Barros, M.R. Continuous purification of antibodies from cell culture supernatant with aqueous two-phase systems: From concept to process. Biotechnol. J. 2013, 8, 352-362.

148. Chatel, A.; Kumpalume, P.; Hoare, M. Ultra scale-down characterization of the impact of conditioning methods for harvested cell broths on clarification by continuous centrifugationrecovery of domain antibodies from rec E. coli. Biotechnol. Bioeng. 2014, 111, 913-924.

149. Müller-Späth, T.; Krättli, M.; Aumann, L.; Ströhlein, G.; Morbidelli, M. Increasing the activity of monoclonal antibody therapeutics by continuous chromatography (MCSGP). Biotechnol. Bioeng. 2010, 107, 652-662.

150. Zobel, S.; Helling, C.; Ditz, R.; Strube, J. Design and operation of continuous countercurrent chromatography in biotechnological production. Ind. Eng. Chem. Res. 2014, 53, 9169-9185.

151. Liu, Z.; Bartlow, P.; Varakala, R.; Beitle, R.; Koepsel, R.; Ataai, M.M. Use of proteomics for design of a tailored host cell for highly efficient protein purification. J. Chromatogr. A 2009, 1216, 2433-2438.

(C) 2014 by the authors; licensee MDPI, Basel, Switzerland. This article is an open access article distributed under the terms and conditions of the Creative Commons Attribution license (http://creativecommons.org/licenses/by/4.0/). 